An Introduction to

Electrical Circuit Theory 


\section{Some Other ELBS Low-priced Editions}

\begin{tabular}{|c|c|c|}
\hline $\begin{array}{l}\text { Benson and } \\
\text { Harrison }\end{array}$ & EleGtric-CirCutT Theory & Edward Arnold \\
\hline Betts & Signal Processing, Modulation and Noise & $\begin{array}{l}\text { Hodder } \mathbb{E}^{2} \\
\text { Stoughton }\end{array}$ \\
\hline $\begin{array}{l}\text { Brown and } \\
\text { Glazier }\end{array}$ & TELECOMMUNications & $\begin{array}{l}\text { Chapman } \\
\text { Hall }\end{array}$ \\
\hline Bryan & Control Systems for Teghnicians & $\begin{array}{l}\text { Hodder } \mathcal{E}^{2} \\
\quad \text { Stoughton }\end{array}$ \\
\hline Douce & $\begin{array}{l}\text { AN INTRODUCTION TO THE MATHEMATICS OF } \\
\text { SERVOMECHANISMS }\end{array}$ & $\begin{array}{l}\text { Hodder } \mathcal{E}^{2} \\
\quad \text { Stoughton }\end{array}$ \\
\hline Dover & Electric Traction & Pitman \\
\hline Draper & EleGtrical MaGhines & Longman \\
\hline Francis & ElECTRICAL InSTALLATION WORK & Longman \\
\hline Fraser & Telecommunications & Macdonald \\
\hline Gregory & $\begin{array}{l}\text { AN INTRODUCTION TO ELEGTRICAL } \\
\text { INSTRUMENTATION }\end{array}$ & Macmillan \\
\hline Hughes & Electrical Technology & Longman \\
\hline Jeffrey & Mathematics for EngineERS AND SCIENTISTS & Nelson \\
\hline John & AN Introduction to EngineERING Materials & Macmillan \\
\hline Lewin & Logical Design of Switching Circuits & Nelson \\
\hline $\begin{array}{l}\text { Morley and } \\
\text { Hughes }\end{array}$ & Principles of Electricity & Longman \\
\hline $\begin{array}{l}\text { Paddock and } \\
\text { Galvin }\end{array}$ & $\begin{array}{l}\text { ElEGTRICAl Installation TeGhNOLOGY } \\
\text { and Practice }\end{array}$ & $\begin{array}{l}\text { Hodder } \mathbb{E} \\
\text { Stoughton }\end{array}$ \\
\hline $\begin{array}{l}\text { Shepherd, Morton } \\
\text { and Spence }\end{array}$ & Higher Electrical Engineering & Pitman \\
\hline Say & $\begin{array}{l}\text { The Performance and Design of A.C. } \\
\text { Machines }\end{array}$ & Pitman \\
\hline Spain & VEGTOR ANALYSIS & $\begin{array}{l}\text { Van Nostrand, } \\
\text { London }\end{array}$ \\
\hline Stephenson & $\begin{array}{l}\text { An Introduction to Partial Differential } \\
\text { EQUATIONS }\end{array}$ & Longman \\
\hline Stephenson & Mathematical Methods For Scientists & Longman \\
\hline Starr & $\begin{array}{l}\text { GENERATION, Transmission aNd Utilization } \\
\text { OF EleGtrical PoWER }\end{array}$ & Pitman \\
\hline $\begin{array}{l}\text { Young and } \\
\text { Griffiths }\end{array}$ & AUTOMOBILE ELEGTRICAL EQUIPMENT & $\begin{array}{l}\text { Newnes- } \\
\text { Butterworths }\end{array}$ \\
\hline
\end{tabular}


An Introduction to

\section{Electrical Circuit Theory}

G. Williams

Lecturer in Electrical Engineering

School of Applied Sciences

University of Sussex

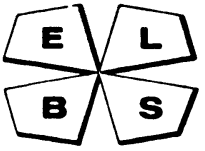

Macmillan Education 
(C) G. Williams 1973

All rights reserved. No part of this publication may be reproduced or transmitted, in any form or by any means, without permission.

First edition 1973

Reprinted 1975 (with corrections), 1977

ELBS edition first published 1977

Published by

THE MACMILLAN PRESS LTD

London and Basingstoke

Associated companies in Delhi Dublin

Hong Kong Johannesburg Lagos Melbourne

New York Singapore and Tokyo

ISBN 978-o-333-23385-6 ISBN 978-1-349-03637-o (eBook)

DOI 10.1007/978-1-349-03637-o

The paperback edition of this book is sold subject to the condition that it shall not, by way of trade or otherwise, be lent, resold, hired out, or otherwise circulated without the publisher's prior consent in any form of binding or cover other than that in which it is published and without a similar condition including this condition being imposed on the subsequent purchaser. 


\section{Contents}

Preface

ix

1 BASIC DEFINITIONS AND CIRCUIT LAWS 1

1.1 Units and dimensions 1

1.1.1 Electrical quantities 1

1.1.2 Dimensional analysis 3

1.2 The circuit element of resistance 4

1.2.1 Ohm's law 5

1.2.2 Non-linear resistors 7

1.2.3 Power dissipated by resistors 7

1.3 Kirchhoff's laws 8

$\begin{array}{lll}\text { 1.3.1 Sign conventions } & 8\end{array}$

1.3.2 Ideal circuit elements 9

$\begin{array}{ll}1.3 .3 \text { Current law } & 10\end{array}$

$\begin{array}{lll}1.3 .4 & \text { Voltage law } & 11\end{array}$

$\begin{array}{ll}\text { 1.3.5 Applications of Kirchhoff's laws } & 12\end{array}$

$\begin{array}{ll}\text { Problems } & 16\end{array}$

2 METHODS OF ANALYSIS AND NETWORK THEOREMS 18

2.1 Terminology and network topology 18

2.2 The basic method of network analysis 21

2.2.1 Worked example 22

2.3 Mesh analysis 23

2.3.1 Mesh currents 23

2.3.2 Method of mesh analysis 24

2.3.3 Worked example 25

2.3.4 General solution 25

2.4 Nodal analysis 26

2.4.1 Method of nodal analysis $\quad 27$

2.4.2 Worked example 27

2.4.3 General solution 28

2.4.4 Mesh or nodal analysis? $\quad 29$ 
2.5 Duality

2.5.1 Dual networks $\quad 29$

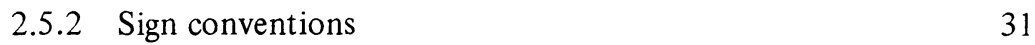

$\begin{array}{ll}2.5 .3 \text { Worked example } & 32\end{array}$

$\begin{array}{lll}2.6 & \text { Sources } & 32\end{array}$

$\begin{array}{lll}2.6 .1 & \text { Representation of physical sources } & 33\end{array}$

$\begin{array}{ll}2.6 .2 \text { Source equivalence } & 35\end{array}$

$\begin{array}{ll}2.6 .3 \text { Compound sources } & 35\end{array}$

2.6.4 Resistanceless sources $\quad 36$

2.6.5 Maximum power transfer theorem $\quad 39$

$\begin{array}{lll}2.7 & \text { Network theorems } & 40\end{array}$

$\begin{array}{lll}2.7 .1 & \text { Linearity } & 40\end{array}$

2.7.2 Superposition theorem 41

2.7.3 Star-delta transformation $\quad 43$

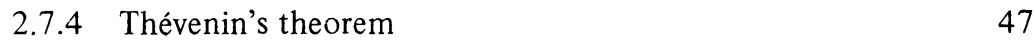

$\begin{array}{lll}2.7 .5 & \text { Norton's theorem } & 49\end{array}$

2.7.6 Reciprocity theorem $\quad 51$

2.8 Equivalent $\mathrm{T}$ and $\Pi$ circuits $\quad 52$

2.8.1 Two-port parameters $\quad 53$

2.8.2 Equivalent T circuits $\quad 54$

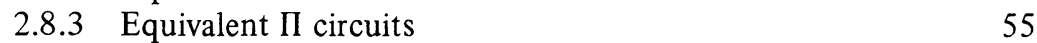

$\begin{array}{lll}2.8 .4 & \Pi-T \text { equivalence } & 56\end{array}$

$\begin{array}{ll}\text { Problems } & 56\end{array}$

\section{THE CIRCUIT ELEMENTS OF CAPACITANCE AND INDUCTANCE}

$\begin{array}{lll}3.1 & \text { Capacitance } & 61\end{array}$

3.1.1 Definition 61

$\begin{array}{ll}3.1 .2 & \text { Volt-ampere equations }\end{array}$

$\begin{array}{lll}3.1 .3 & \text { Energy stored } & 63\end{array}$

3.1.4 Capacitances in parallel $\quad 64$

3.1.5 Capacitances in series $\quad 65$

$\begin{array}{ll}3.2 \text { Inductance } & 66\end{array}$

3.2.1 Definition of self-inductance $\quad 66$

$\begin{array}{ll}3.2 .2 & \text { Volt-ampere equations } \\ 3.2 .3 & 67\end{array}$

$\begin{array}{lll}3.2 .3 & \text { Energy stored } & 68\end{array}$

$\begin{array}{ll}3.2 .4 & \text { Inductances in series }\end{array}$

3.2.5 Inductances in parallel $\quad 69$

$\begin{array}{lll}3.3 & \text { Duality } & 70\end{array}$

$\begin{array}{lll}3.4 & \text { Mutual inductance } & 70\end{array}$

$\begin{array}{ll}\text { 3.4.1 Definition of mutual inductance } & 70\end{array}$

$\begin{array}{lll}3.4 .2 & \text { Volt-ampere equations } & 71\end{array}$

$\begin{array}{lll}3.4 .3 & \text { Equivalent voltage generators } & 72\end{array}$

$\begin{array}{lll}\text { 3.4.4 Coefficient of coupling } & 73\end{array}$

3.4.5 Magnetic energy stored by mutual inductance 73

Problems 
4 TRANSIENT RESPONSE OF FIRST- AND SECOND-ORDER NETWORKS

4.1 Differential equations of first-order networks 78

$\begin{array}{ll}\text { 4.1.1 Initial conditions } & 78\end{array}$

$\begin{array}{lll}4.1 .2 & \text { Final conditions } & 80\end{array}$

4.1.3 Application of the basic analytical method 81

$\begin{array}{ll}\text { 4.1.4 Mesh analysis } & 82\end{array}$

4.1.5 Nodal analysis $\quad 82$

4.1.6 Application of network theorems 83

4.2 Natural response of first-order networks 83

4.2.1 RC circuit $\quad 83$

4.2.2 RL circuit $\quad 85$

4.3 Some steady-state responses of first-order networks $\quad 86$

4.3.1 Series $R L$ circuit excited by a step function $\quad 86$

4.3.2 Series $R C$ circuit excited by a step function $\quad 87$

4.3.3 Series $R L$ circuit excited by a sinusoidal function $\quad 87$

4.4 Total response of first-order networks $\quad 89$

4.4.1 Step response of $R L$ circuits $\quad 89$

4.4.2 Repetitive step response of $R L$ circuit 91

4.4.3 Step response of $R C$ circuit $\quad 92$

4.4.4 Repetitive step response of $R C$ circuit 93

4.5 Differential equations of second-order networks 95

4.6 Natural response of second-order networks 96

4.6.1 Overdamped case 98

4.6.2 Critically damped case 99

$\begin{array}{ll}\text { 4.6.3 Underdamped case } & 100\end{array}$

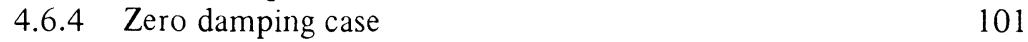

4.6.5 Definitions 101

4.7 Step response of second-order networks 102

$4.8 Q$-factor 104

Problems 104

5 STEADY-STATE SINUSOIDAL RESPONSE OF NETWORKS 110

5.1 Response of series $R L C$ circuit $\quad 110$

5.2 Frequency response 113

5.2.1 Amplitude 113

5.2.2 Phase 113

$5.3 Q$-factor, bandwidth and resonance 114

5.4 A.C. quantities 118

5.4.1 Instantaneous, mean and r.m.s. values 119

5.4.2 Real and reactive power $\quad 122$

5.5 Representation of sinusoids 127

$\begin{array}{lll}\text { 5.5.1 Rotating vectors } & 127\end{array}$

5.5.2 Complex number representation of sinusoids 132 
$\begin{array}{lll}5.6 & \text { Frequency-domain analysis } & 136\end{array}$

5.6.1 Volt-ampere equations in the frequency domain 136

$\begin{array}{ll}\text { 5.6.2 Kirchhoff's laws in the frequency domain } & 140\end{array}$

$\begin{array}{ll}\text { 5.6.3 Mesh and nodal analysis } & 141\end{array}$

5.6.4 Impedance and admittance $\quad 144$

$\begin{array}{lll}5.7 & \text { Worked example } & 145\end{array}$

$\begin{array}{lll}\text { 5.7.1 By phasor diagram } & 145\end{array}$

$\begin{array}{ll}\text { 5.7.2 By nodal analysis } & 147\end{array}$

$\begin{array}{ll}\text { 5.7.3 By Thévenin substitution } & 149\end{array}$

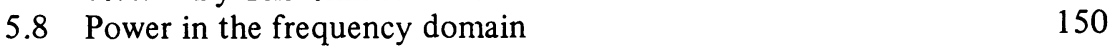

5.8.1 Real, reactive and apparent power 150

$\begin{array}{ll}5.8 .2 \text { Power triangle } & 151\end{array}$

$\begin{array}{ll}\text { 5.8.3 Worked example } & 154\end{array}$

5.8.4 Maximum power transfer theorem $\quad 156$

$\begin{array}{ll}\text { Problems } & 158\end{array}$

6 NETWORK ANALYSIS TECHNIQUES 164

6.1 Two-port networks 164

6.1.1 Open-circuit impedance parameters 165

$\begin{array}{ll}\text { 6.1.2 Short-circuit admittance parameters } & 166\end{array}$

$\begin{array}{ll}\text { 6.1.3 Hybrid parameters } & 167\end{array}$

$\begin{array}{ll}\text { 6.1.4 Inverse-hybrid parameters } & 167\end{array}$

$\begin{array}{ll}\text { 6.1.5 Transmission parameters } & 168\end{array}$

$\begin{array}{ll}\text { 6.1.6 Interrelation of parameters } & 169\end{array}$

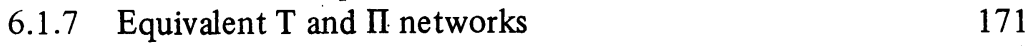

$\begin{array}{ll}6.2 \text { Ideal transformer } & 173\end{array}$

$\begin{array}{lll}\text { 6.2.1 Volt-ampere equations } & 173\end{array}$

$\begin{array}{ll}\text { 6.2.2 Impedance transformation } & 175\end{array}$

$\begin{array}{ll}\text { 6.2.3 Voltage and magnetic flux waveforms } & 176\end{array}$

$\begin{array}{lll}6.2 .4 & \text { Phasor diagrams } & 177\end{array}$

$\begin{array}{ll}\text { 6.2.5 Worked example } & 179\end{array}$

$\begin{array}{lll}6.3 & \text { Bridge networks } & 182\end{array}$

$\begin{array}{ll}\text { 6.3.1 Wheatstone bridge } & 183\end{array}$

$\begin{array}{ll}\text { 6.3.2 Maxwell bridge } & 183\end{array}$

$\begin{array}{lll}6.4 & \text { Polyphase circuits } & 184\end{array}$

$\begin{array}{ll}\text { 6.4.1 Balanced three-phase voltages } & 184\end{array}$

$\begin{array}{ll}\text { 6.4.2 Balanced three-phase currents } & 188\end{array}$

$\begin{array}{ll}\text { 6.4.3 Three-phase power } & 191\end{array}$

6.5 Non-linear circuits-load line and linear approximation 192

6.5.1 Non-linear elements 193

$\begin{array}{ll}\text { 6.5.2 Analytical techniques } & 194\end{array}$

$\begin{array}{ll}\text { Problems } & 198\end{array}$

Solutions to Problems 200

$\begin{array}{ll}\text { Index } & 205\end{array}$ 


\section{Preface}

Many textbooks owe their origins to undergraduate lecture courses; this book had its beginnings in a lecture course in engineering science given by the author at the University of Sussex. When the course was begun several years ago the familiar problem of not being able to recommend a single, inexpensive, book to the students taking the course was encountered. The nature of the course structure at Sussex with its major and minor subjects made the problem more difficult because the students attending the course included not only electrical and electronic engineers but undergraduates from many other scientific disciplines too. Educational experiments in the presentation of course material being conducted at the time also meant that printed lecture notes were prepared for the course and it is with these that this book had its beginnings.

While the course contained much circuit theory other topics were included which do not appear here and conversely this book contains several topics not covered in the course. The additional material has been included so that the book may be considered to be an introduction to the subject of circuit theory viewed as a separate discipline and not viewed as a service subject to other disciplines.

The philosophy governing the presentation of the material is that all the circuit laws, methods of analysis and circuit theorems are developed using the simplest possible circuits containing only resistances and d.c. sources. Thus the discussion is not clouded by the examination of the more complicated circuit elements and sources which introduce time variations; the intention is for the student to master the analytical techniques before he goes on to apply them to the more complicated circuits. Application of the techniques to frequency domain circuits is then a logical step which allows the student to concentrate on the frequency domain concepts.

The background knowledge of readers is assumed to be school mathematics and physics but to include no circuit theory. It is also assumed that students will be covering such topics as complex numbers, second-order differential equations and linear algebra simultaneously with their studies of circuit theory and such mathematical topics are not discussed in detail here.

I would like to acknowledge the advice, co-operation and support I have received from my colleagues at the University of Sussex. It is also no cliché to say that this book could not have been created without the active assistance, tolerant 
understanding and unflagging encouragement of my wife.

Many of the problems in this book were originally devised by me for Preliminary Year examinations of the University of Sussex and I am grateful to the University of Sussex for permitting me to use them.

G.W. 